\title{
Chapter 10 \\ Non-additionality, Overestimation \\ of Supply, and Double Counting in Offset \\ Programs: Insight for the Mexican \\ Carbon Market
}

\section{Marcela López-Vallejo}

\begin{abstract}
Mexico utilizes an emissions trading system as one of its carbon pricing instruments. Mexico's planning, like that of other countries, includes flexible mechanisms such as offsets. Offsets allow market participants to compensate for their emissions through mitigation projects. Offsetting via participation in the Clean Development Mechanism and Joint Implementation was fundamental to the Kyoto Protocol. In contrast, the Paris Agreement is ambiguous about its use. Other national or regional offset programs, such as the EU, Australia, New Zealand, Japan, or Korea, work within emission trading systems. Subnationally, the California-Quebec program has been in effect since 2014. As Greenhouse Gases (GHGs) are global, offsetting allows market participants to compensate for their emissions through mitigation projects, whether domestically or abroad. Given their global scope, such programs present a wide variability in quality. This chapter presents an overview of offset programs worldwide and argues that non-additionality, overestimated supply, and double counting are their three most pressing quality problems. This analysis sheds light upon the nascent Mexican system and its offset program.
\end{abstract}

Keywords Mexico $\cdot$ ETS $\cdot$ Offsets $\cdot$ Supply $\cdot$ Additionality $\cdot$ Double counting

\section{Introduction}

Mexico takes part in more than 40 carbon pricing initiatives that utilize Emissions Trading Systems (ETS) (World Bank 2019: 13). A common instrument for extending mitigation options is offsetting, which seems to have regained importance after the 2015 Paris Agreements. ETS and offset programs were designed on a global scope in the 1990s by the United Nations through a regime supported by the United States Framework Convention on Climate Change (UNFCCC) and the Kyoto Protocol (KP) (Meckling and Hepburn 2013; Egenhofer 2013).

\footnotetext{
M. López-Vallejo (凶)

Departamento de Estudios del Pacífico (CUCSH), Centro de Estudios Sobre América del Norte, Universidad de Guadalajara, Zapopan, Jalisco, Mexico

e-mail: marcela.lopezvallejo@academicos.udg.mx
} 
The KP allowed for Annex I countries to acquire Certified Emissions Reductions (CER) through three market-based instruments: an emissions trading system and two offset programs, Clean Development Mechanism (CDM) and Joint Implementation (JI) (Kyoto Protocol 1997). In the KP ETS, one country could reach its mitigation goals by transferring part of its assigned emissions to other countries that had fewer and could thus compensate for their pollution. Offset programs promoted the development of climate-mitigation projects in other nations. Under CDM and JI, polluting countries, especially developing nations, paid for these projects (Egenhofer 2013: 359; Meckling and Hepburn 2013: 476).

Although pricing initiatives and ETS are subject to criticism and face many detractors among scholars, practitioners, and NGOs (Swyngedouw 2016; Alcock 2008; Monbiot 2006), they are for others an essential part of the public policy toolkit for addressing climate change (Egenhofer 2013: 359; Ellerman et al. 2010). ETS seem to have some advantages over other pricing strategies, such as taxes. Martínez (2019) and Rabe (2018) make the case for ETS as they are useful in mitigating GHG and meet an amount of country reduction targets without using public resources or politicizing price-setting. ETS are also perceived as a socio-environmental technology-transfer mechanism among countries or market participants (Martínez 2019; Rabe 2018). Rabe (2018: 8) notes that ETS and cap-and-trade systems deliver the exact level of emissions reductions by enforcing non-compliance penalties. This helps offer jurisdictions predictability when it comes to advancement toward their targets. That is, ETS participants are informed of short-term expectations and long-term adjustments they need to make.

Apart from the KP ETS, there are other systems with regional, national, or subnational approaches to using offset credits. The European Union (EU) pioneered the use of ETS and offsets, putting this system in place to comply with its KP commitments. Other countries followed and designed their own systems, such as Australia, New Zealand, Japan, and Korea, among others (Egenhofer 2013). Although the most commonly used mechanism for ETS is cap-and-trade, other schemes are also in effect. Australia uses a baseline-and-credit system and the Canadian province of British Columbia works within a baseline-and-offsets structure.

Subnationally, Quebec and California inaugurated their joint ETS in 2014. This was later the basis for other Canadian provinces to design individual schemes, aiming to join this regional system to comply with federal legislation. In the US, the Regional Greenhouse Gas Initiative has served as an ETS since 2011 and, as in Canada, other states are developing their own ways to join the regional initiative (Rabe 2018; López-Vallejo 2014). China's subnational ETS pilots informed and evolved into a national market (Zhang and Zhou 2020). Some new national initiatives, like the Mexican carbon cap-and-trade system, are starting to pilot ETS schemes. All national and subnational ETS have offsetting programs. Some jurisdictions have even reshaped their ETS in attempts to adapt to their Nationally Determined Contribution as submitted to the Paris Agreement. This is the case of the EU, New Zealand, Kazakhstan, Regional Greenhouse Gas Initiative (RGGI), and California (World Bank 2019). Despite these efforts, carbon prices are still too low to comply with the Paris Agreements. In 2019, prices ranged from \$1USD to \$35USD a tonne of $\mathrm{CO}_{2 \mathrm{eq}}$ 
(Broekhoff et al. 2019: 9; World Bank 2019). Experts note that if the world truly aims to comply with the Paris Agreement, offset programs should disappear slowly over time, as ambition requires achieving net-zero GHG emissions in this century (Dufrasne 2018).

Until the world achieves said neutrality, offset programs are useful to complement climate regulation or ETS. As GHGs are global and it does not matter where exactly they are reduced (Broekhoff et al. 2019), offsetting allows market participants to compensate for their emissions through mitigation projects domestically or abroad. These account for quality variability or how the projects preserve environmental integrity (Broekhoff et al. 2019: 18). Experts categorize them in Type A being focused and setting specific policy targets, whereas Type B help other ETS policies as they have broader goals. Type $\mathrm{C}$ is the most comprehensive; it influences other climate or clean energy policies (Gillenwater 2012; PMR 2015; Michaelowa 2011). These help countries to reach global GHG targets at lower costs to society than regulation policies do and can function as a technology and funding transfer mechanism (Egenhofer 2013: 359). Mexico's trading system utilizes offsets as a flexibility mechanism.

This chapter contends that offset programs usually present three major quality problems: non-additionality, overestimated supply, and double counting (Broekhoff et al. 2019; Michaelowa 2011). It further explains these problematic issues and gives recommendations to try to prevent them in the nascent Mexican market. The first two sections present an overview of offset programs worldwide, their characteristics, and scope. The third section analyses why non-additionality, overestimated supply, and double counting are problematic issues for offset programs. In the fourth part, these three issues are discussed along with the current structure of the Mexican market trials. Lessons learned by other programs need to be taken into account for the success of the Mexican initiative. This chapter then concludes with the final section offering recommendations.

\section{Overview of Offset Programs Worldwide}

An offset is a mechanism compensating for emissions by investing in environmental projects beyond regulated participants or in other market jurisdictions (World Bank 2019; PMR 2015; Egenhofer 2013; Meckling and Hepburn 2013; Fujiwara and Egenhofer 2007). An offset credit is a "transferable instrument certified by governments or independent certification bodies to represent an emission reduction of one metric tonne of $\mathrm{CO}_{2}$, or an equivalent amount of other GHGs" (Broekhoff et al. 2019: 6). Offsets work when ETS participants pay an extra quota to compensate for greenhouse gas emissions from specific projects or standards (Broekhoff et al. 2019; PMR 2015; Egenhofer 2013). They can compensate for individual or companies' entire pollution or for specific sector caps. They function for example when a company makes up for its emissions by financing reforestation, transportation, ecotourism, agriculture, waste, buildings, or clean energy projects elsewhere. 
As Broekhoff et al. (2019: 8) suggest, offset programs worldwide have three goals: (1) to develop and approve quality eligibility criteria or standards for offset credits, (2) to develop registries of projects and assess them against these criteria, and (3) to operate the credit transfers. The use of offsets in ETS lowers costs of compliance with socio-environmental policies or regulations by allocating additional funds to specific domestic or international projects (Martínez 2019; Matsuki 2015; Fujiwara and Egenhofer 2007). If international, the range of options is wider but more difficult to standardize and more costly to operate. When offsetting is performed domestically (regionally, within the jurisdiction, or within a sector), compliance costs can be lower, encouraging non-capped participants to move toward decarbonization in a controlled environment (Fujiwara and Egenhofer 2007: 19).

Offset programs range from international intergovernmental to those run by national or subnational governments and to voluntary efforts, generally operated by non-governmental institutions. Of these, some are independent and others are linked to ETS with cap-and-trade systems. The two most important international and intergovernmental offset programs are the Clean Development Mechanism (CDM) and the Joint Implementation (JI) in operation through the Kyoto Protocol. They work globally, and participants may include countries that are official members of the protocol, along with private or voluntary buyers (PMR 2015; Egenhofer 2013; Marcu 2012). As the PMR (2015) reports, the CDM offered Annex I countries offset projects to meet their specific KP targets. The offset credits were allocated to developing countries that had ratified the protocol. The JI linked Annex I countries to help meet their reduction targets.

Together, these programs accounted for the majority of offsetting practices worldwide (PMR 2015). Nonetheless, CDM and JI present serious problems. Research by Cames et al. (2016: 11) suggests that around 85\% of offset credits from the CDM up to 2012 , and $73 \%$ of the $2013-2020$ projects may not have led to real emission reductions, especially with industrial gas destruction and other such projects in the energy sector; this may have resulted in an increase of roughly 600 million metric tonnes of emissions through 2015.

Since the Paris Agreement (2015) was ambiguous regarding their use, the permanence of CDM and JI has been debated. Advocates for environmental integrity and ambition tend to suggest discarding them (Carbon Market Watch 2019; Dufrasne 2018). At COP25 in Madrid in 2019, Article 6 of the agreement (addressing voluntary cooperation approaches, such as ETS and offset programs) was still pending. Negotiators could not agree upon several issues. Article 6.8 includes non-market cooperation mechanisms, which are not yet defined. Article 6.2 was more controversial, as it refers to helping reduce NDC emissions through cooperative approaches involving Internationally Transferred Mitigation Outcomes (ITMOs). However, the Paris Agreement parties could not reach a consensus for designing a trustworthy global offset accounting system. The main goal of a solid system is to prevent doublecounting practices common in the CDM and JI, where emission reduction figures were counted simultaneously by both cooperation partners (Alloisio 2020; Environmental Defense Fund 2019; Schneider and La Hoz Theuer 2018; Gehring and Phillips 2017). 
The third source of the debate was Article 6.4, which establishes a Sustainable Development Mechanism (SDM), to be supervised by a body determined by the COP. A third party could guarantee that offset projects met COP criteria or standards (Alloisio 2020; Gehring and Phillips 2017). COP also facilitates direct access for offsetting SDM to the private sector and other social actors.

The second type of offset programs is either national or subnational, generally linked to mitigation policies and cap-and-trade systems. These programs can be found in the European Union, Australia, China, California, Quebec, Nova Scotia, Alberta, Switzerland, and Japan (Broekhoff et al. 2019: 9; PMR 2015; Egenhofer 2013: 365-367). For example, the two North American carbon markets, CaliforniaQuebec (called the WCI market, which, since 2019, also includes Nova Scotia) and Regional Greenhouse Gas Initiative (RGGI), utilize offsets to promote projects within their member jurisdictions (Rabe 2018; López-Vallejo 2014). In 2020, the percentage of offsets allowed in these ETS ranged from 8 to $12 \%$ and prices from \$8USD to \$18USD per tonne. Offsets under such programs usually address sectors not covered by other mitigation policies and ETS (PMR 2015).

The third type of offset programs is non-governmental or voluntary, such as Gold Standard (GS), Climate Action Reserve (CAR), or Verified Carbon Standard (VCS). GS was established in 2003 by the World Wildlife Fund and a coalition of other NGOs to promote sustainability in CDM projects (Gehring and Phillips 2017; Meckling and Hepburn 2013). CAR proposes specific protocols for various project types. These may involve coal mine methane, forests, grasslands, nitric acid, nitrogen management, organic waste digestion, rice cultivation, urban forest management, and urban tree planting (Gehring and Phillips 2017: 5). VCS includes a set of parallel standards to generate verified carbon units for emissions reduction (Egenhofer 2013).

These programs complement governmental carbon markets. For example, GS aids CDM and JI voluntary programs; CAR and VCS verify the California-Quebec ETS (PMR 2015). California utilizes voluntary verification, monitoring, and compliance with its offset programs, the American Carbon Registry Standard (ACR) (Gehring and Phillips 2017: 5). Such voluntary programs have two main features: they are verifiable through constant auditing, guaranteeing that offset projects work as they promised. They also require projects to offer social benefits at a local level (PMR 2015). Some voluntary programs are linked to others, such as REDD+, which has caused debate as REDD+ projects are usually difficult to verify.

\section{Characteristics of Offset Programs and Projects}

There are significant differences among offset programs. Gillenwater (2012) proposes that they be substantially categorized, with their goals and scope specified. Table 10.1 shows three types of programs and their characteristics.

In general, Type A programs have specific targets and are less ambitious but more focused: KP offset programs are examples of this. Newly developed programs, like those nascent in Mexico, tend to start with this approach. Type B shares Type A 
Table 10.1 Types of offset programs according to their goals

\begin{tabular}{|c|c|c|c|c|}
\hline & $\begin{array}{l}\text { Goal of offset } \\
\text { program }\end{array}$ & $\begin{array}{l}\text { Operative } \\
\text { characteristics }\end{array}$ & Pricing & Allocation \\
\hline Type A & $\begin{array}{l}\text { Giving income or } \\
\text { funds through offset } \\
\text { credits and sending } \\
\text { a pricing signal }\end{array}$ & $\begin{array}{l}\text { Resembling a } \\
\text { subsidy }\end{array}$ & $\begin{array}{l}\text { Depending on the } \\
\text { supply and demand } \\
\text { of credits } \\
\text { (stakeholders' } \\
\text { proposals for } \\
\text { projects) }\end{array}$ & $\begin{array}{l}\text { - Where it can } \\
\text { make the most } \\
\text { significant } \\
\text { change of } \\
\text { behaviour } \\
\text { - Sector-based } \\
\text { - Can be } \\
\text { standardized or } \\
\text { project based }\end{array}$ \\
\hline Type B & $\begin{array}{l}\text { Promoting other } \\
\text { ETS policy } \\
\text { instruments directly } \\
\text { linked to the offset } \\
\text { program }\end{array}$ & $\begin{array}{l}\text { Direct funding plus: } \\
\text { - Capacity building, } \\
\text { technical, } \\
\text { educational, legal, } \\
\text { and financial } \\
\text { support } \\
\text { - Enforcement } \\
\text { instruments } \\
\text { - Recognition of } \\
\text { advances or } \\
\text { shaming programs }\end{array}$ & $\begin{array}{l}\text { Uncertainty of } \\
\text { subsidies depending } \\
\text { on market, but } \\
\text { certainty on } \\
\text { concrete projects } \\
\text { related to other } \\
\text { policy instruments } \\
\text { Tending to lower } \\
\text { transaction costs of } \\
\text { offsets and ETS } \\
\text { policies }\end{array}$ & $\begin{array}{l}\text { - Financial and } \\
\text { non-financial } \\
\text { factors are taken } \\
\text { into account } \\
\text { - Allocation to } \\
\text { offset program } \\
\text { but with broader } \\
\text { ETS policy } \\
\text { criteria }\end{array}$ \\
\hline Type C & $\begin{array}{l}\text { Generating broad } \\
\text { market effects }\end{array}$ & $\begin{array}{l}\text { New market } \\
\text { developments (other } \\
\text { than baselines) }\end{array}$ & $\begin{array}{l}\text { Including non-offset } \\
\text { prices (trying to } \\
\text { prevent leakage or } \\
\text { non-compliance) }\end{array}$ & $\begin{array}{l}\text { Within the offset } \\
\text { program and } \\
\text { Indirectly outside } \\
\text { the offset program } \\
\text { (spillover effect) }\end{array}$ \\
\hline
\end{tabular}

Source Author's elaboration with information from Gillenwater (2012), PMR (2015), Michaelowa (2011)

features but goals are broader, as programs aim to aid other ETS policies. They offset emissions and develop local renewable markets: CAR and VCS are linked, for example, to Renewable Portfolio Standards as in the California-Quebec offset program. National programs tend to fall within this type. Type $\mathrm{C}$ is the most complex as it includes both A and B. It aims to modify participant behaviour and impact ETS, policy instruments, and other social agents. Some programs, for example, require projects to have social co-benefits, as in the EU program or the proposed version of the SDM. Voluntary programs, such as GS, even strive to implement the Sustainable Development Goals.

Within offset programs, quality assessment is fundamental to overcoming problems. The quality of projects is generally measured by how well they prevent practices of non-additionality, overestimated supply, and double counting. As the baseline is generally established by business, as usual, it is critical to assess which projects contribute more to an offset program and environmental integrity. Table 10.2 summarizes the most common types of projects and what experts perceive to be their main strengths or weaknesses. 
Table 10.2 Type of projects and quality

\begin{tabular}{|c|c|c|c|}
\hline Type & Quality $^{\mathrm{a}}$ & Co-benefits & Risks \\
\hline $\begin{array}{l}\text { Renewable energy (small } \\
\text { scale) }\end{array}$ & High & $\begin{array}{l}\text { Reduced air } \\
\text { pollution/off-grid } \\
\text { electrification }\end{array}$ & $\begin{array}{l}\text { Baseline uncertainty easily } \\
\text { addressed by eligibility } \\
\text { criteria/big investment and } \\
\text { uncertain GHG reduction }\end{array}$ \\
\hline $\begin{array}{l}\text { Energy efficiency } \\
\text { (household) }\end{array}$ & High & $\begin{array}{l}\text { Prompt energy } \\
\text { transition/lower costs of } \\
\text { energy }\end{array}$ & $\begin{array}{l}\text { Baseline uncertainty easily } \\
\text { addressed by eligibility } \\
\text { criteria/covered by } \\
\text { regulation or industrial } \\
\text { standards already }\end{array}$ \\
\hline Methane destruction & High & $\begin{array}{l}\text { Reduced air pollution (and } \\
\text { odors) in localities }\end{array}$ & $\begin{array}{l}\text { Baseline uncertainty easily } \\
\text { addressed by eligibility } \\
\text { criteria/normally covered } \\
\text { by regulation }\end{array}$ \\
\hline Energy distribution & Medium & $\begin{array}{l}\text { Air quality } \\
\text { upgrade/connect off-grid } \\
\text { communities }\end{array}$ & $\begin{array}{l}\text { Capital intensive } \\
\text { projects/covered by } \\
\text { regulation already }\end{array}$ \\
\hline $\begin{array}{l}\text { Renewable energy (large } \\
\text { scale) }\end{array}$ & Medium & $\begin{array}{l}\text { Help consolidate industrial } \\
\text { change }\end{array}$ & $\begin{array}{l}\text { Already covered by } \\
\text { regulation and } \\
\text { baselines/local social and } \\
\text { environmental disruption }\end{array}$ \\
\hline $\begin{array}{l}\text { Methane capture or } \\
\text { utilization }\end{array}$ & Medium & $\begin{array}{l}\text { Energy generation and } \\
\text { benefits to health }\end{array}$ & $\begin{array}{l}\text { Baseline uncertainty } \\
\text { addressed by rules and } \\
\text { eligibility criteria/could be } \\
\text { seen as supporting } \\
\text { polluting industries }\end{array}$ \\
\hline $\begin{array}{l}\text { Industrial gases avoidance } \\
\text { (PFCs and } \mathrm{SF}_{6} \text { ) }\end{array}$ & Medium & $\begin{array}{l}\text { High probability to be } \\
\text { covered by regulation }\end{array}$ & $\begin{array}{l}\text { Overproduction to attract } \\
\text { credits/no incentive to stop } \\
\text { polluting }\end{array}$ \\
\hline $\begin{array}{l}\text { Energy efficiency } \\
\text { (industrial) }\end{array}$ & Low & $\begin{array}{l}\text { Involve industry/slow } \\
\text { energy transition }\end{array}$ & $\begin{array}{l}\text { Support of polluting } \\
\text { industries/not meeting the } \\
\text { Paris Agreement goals }\end{array}$ \\
\hline $\begin{array}{l}\text { Fossil fuel switching (to } \\
\text { gas) }\end{array}$ & Low & Prevent coal and oil & $\begin{array}{l}\text { Slow energy transition/not } \\
\text { meeting the Paris } \\
\text { Agreement goals }\end{array}$ \\
\hline Forestry and land use & Low & $\begin{array}{l}\text { Local social benefits } \\
\text { (involvement of } \\
\text { people)/provide ecosystem } \\
\text { services }\end{array}$ & $\begin{array}{l}\text { Long-term results and } \\
\text { difficulty to measure in } \\
\text { time/risk of reversal or } \\
\text { non-permanence of } \\
\text { projects }\end{array}$ \\
\hline Agriculture & Low & $\begin{array}{l}\text { Improvement of } \\
\text { technology for local people }\end{array}$ & $\begin{array}{l}\text { Linking to environmental } \\
\text { problems (water pollution } \\
\text { and scarcity, or } \\
\text { deforestation) }\end{array}$ \\
\hline
\end{tabular}


Table 10.2 (continued)

\begin{tabular}{l|l|l|l}
\hline Type & Quality $^{\mathrm{a}}$ & Co-benefits & Risks \\
\hline Biomass & Low & $\begin{array}{l}\text { Beneficial use of waste and } \\
\text { renewable energy } \\
\text { production }\end{array}$ & $\begin{array}{l}\text { Indirect reduction of } \\
\text { industry (double } \\
\text { counting)/problems } \\
\text { assessing land use }\end{array}$ \\
\hline Fugitive gas capture & Low & $\begin{array}{l}\text { Helps with energy } \\
\text { transition }\end{array}$ & $\begin{array}{l}\text { Does not prevent the use of } \\
\text { fossil fuels/does not aim } \\
\text { for the Paris Agreement } \\
\text { goals }\end{array}$ \\
\hline Low-carbon transportation & Low & Improve air quality & $\begin{array}{l}\text { Mitigation costs above } \\
\text { offset prices }\end{array}$ \\
\hline
\end{tabular}

Source Author's elaboration with information from Broekhoff et al. (2019), Gehring and Phillips (2017)

${ }^{a}$ Quality is measured by the volume of GHG reductions or removals that are additional, not overestimated, permanent, not claimed by another entity, and not associated with significant social or environmental harms (Broekhoff et al. 2019: 18)

Although general categorizing may be deceptive, it provides a broad view of types that meet benchmarks for quality. Establishing project eligibility criteria needs to be consistent with program goals (Table 10.1): achieving environmental integrity is more likely with less ambitious programs (e.g. Type A) and higher-quality offset projects. Quality projects may foster corporate social responsibility, consolidate community development, or promote the provision of socio-environmental public goods by governments (Broekhoff et al. 2019). Sometimes a buyer must choose lower project quality such as when profitability may be higher, or compliance with environmental criteria greater, and co-benefits less extensive (Broekhoff et al. 2019: 33). Michaelowa (2011: 19) explains that countries or participants must sometimes opt for lower quality projects due to domestic industry pressures affecting international competition: in such cases, the best choice would be technologies in other than directly competitive ways.

\section{Critiquing Offset Programs}

Many experts have strong criticism for offset programs. Some argue that they are an excuse for business as usual because they fail to create incentives for changing behaviour toward climate mitigation (Monbiot 2006). In 2019, during COP25 in Madrid, civil society and some NGOs protested against carbon markets and offsets. Their argument was that carbon offsets do not prevent pollution, but simply relocate it. In other words, offsets serve as "greenwashing" mechanisms, locking in highemitting activities over the long run and discouraging regulation (Broekhoff et al. 2019). Other critical views see them as relying on subjective criteria and methodologies (Broekhoff et al. 2019: 21; Millard-Ball and Ortolano 2010) or as insufficient 
for encouraging developing countries into decarbonization (Wara and Victor 2008). In this sense, offsets are considered environmental externalities, mitigating in one place while transferring pollution elsewhere.

In 2019, the UN even drafted a harsh critique of traditional offsetting practices. The report by Niklas Hagelberg of the United Nations Environmental Program claimed that offsets generally offer free passes to polluters, at unrealistically low cost. To function as a complementary source of mitigation, "they should change the equivalence of $1 \mathrm{MT}$ to 1 offset credit and factor it by the percentage of GHG emissions decrease necessary (45\% reduction) to achieve ambition under the Paris Agreement" (Hagelberg 2019). Supporting this argument, Broekhoff et al. (2019: 13) suggest that, although meeting carbon neutrality goals is desirable, there is the risk of "masking" this achievement by relying on carbon offsets as the primary reduction source. Instead, institutions need to view carbon offsets as merely additional measures for achieving neutrality by 2050 , as pledged by the Paris Agreement. Offset price increases would set necessary thresholds to further change environmental behaviour (Gillenwater 2012).

A more substantial critique deals with project quality within offset programs. In theory, offsets should guarantee that projects reduce GHG. Well-designed and applied reduction measurement methodologies are fundamental. This argument posits three points regarding evidence to challenge offset programs worldwide. First, they may fail to perform as additional mitigation measures because they are part of existing project designs. If additionality cannot be demonstrated, such criticism by sceptical experts is valid. Additionality means that a project needs to demonstrate that it complements other efforts and that it would not have happened without offset funding. Quality also relates to program operation: for projects to succeed, there must be a pool of potential mitigation spaces, technologies, or options. When there is overestimated supply and leakage, offset programs tend to fail. Another quality issue is how projects and GHGs are counted. Sometimes, the same project is counted in different offset systems at different prices. Double counting creates confusion, interferes with prices which can derail the cap-and-trade system, and undermines environmental integrity.

In sum, there is no one-size-fits-all for offset programs, and there are several conditions that affect their design: examples are the scope, market segment, regulatory framework, institutional setting, and technical capacities to operate them (Matsuki 2015). The next section discusses in detail the three quality issues challenging offset programs: non-additionality, overestimation of supply, and double counting.

\section{Problematic Issues: Non-additionality, Overestimating Supply, and Double Counting}

The thorniest issues for offset programs arise from project quality. Unclear definitions of how additional they are, over- or underestimation of supply, and double-counting 
practices are discussed in this section. Gillenwater (2012) and Meckling and Hepburn (2013) suggest that we need better models and understanding to heighten the benefits offset systems offer over alternative pricing policies (e.g. taxes). If offsets do not meet quality criteria, they will be of no use in the context of the Paris Agreement (Dufrasne 2018).

\section{Non-additionality}

Additionality means that an offset project differs from its GHG baseline and is "additional" to expected emission reductions from any regulation or ETS cap (Gillenwater 2012: 26; Michaelowa 2011: 18-19). In other words, a project is additional when it is prompted by the offset program, not by policies or other factors (e.g. technological advances, incoming investment and projects from external agreements, or new governmental approaches). The projects most often considered additional are those which are not expected to attract investors or governmental funds, are difficult to finance due to technical reasons, are innovative and not considered common practice, have financing sources, face implementation gaps, and that are not mandated by regulatory entities (Broekhoff et al. 2019: 21; Gehring and Phillips 2017: 4). Broekhoff et al. (2019: 19) warn of the common mistake of categorizing a project as additional if it reduces GHG emissions beyond what they would have been without the project. Aside from emissions reduction, the main criteria for using offsets as additional to regulation and ETS is that without the credit a project could not be undertaken at all.

Assessing the additionality of projects can be problematic in two senses. First, offset programs need to demonstrate that they can cause a change in GHG mitigation behaviour via awarded projects. Several CDM offset projects initially failed to provide evidence of additionality, which delegitimized the offset approach (Wara and Victor 2008; Schneider 2007).

There are different approaches for defining additionality worldwide. Michaelowa (2011: 17-18) compares how the EU, the US, and some developing countries confront this. The EU, he explains, has strict definitions using investment tests and ambitious technology benchmarks. In contrast, the US industry favours robust general tests and flexible technical approaches. Least developed countries and islands foster strict additionality which may be effectively reflected in mitigation. Heavily industrialized developing countries (e.g. China and India) adopt a flexible concept of additionality to keep profiting from offsetting.

What is additional and what is not? Broad scope offset types (e.g. Type B and especially Type C, Table 10.1) would need to reject projects which overlap with other policies. This is difficult in the context of an NDC pledge. In contrast, as Type A programs are more specific, they tend to limit the allocation of large-volume offset credits and clearly define GHG reduction calculations (PMR 2015: 6). This proves useful for market participants as it lowers the risk. 
Assessing additionality also varies by whether the program is project-specific or standard-focused. Project-specific approaches contextualize additionality, making the definition of objective criteria difficult. In contrast, approaches relying on standards evaluate smaller sets of projects under pre-determined eligibility criteria, reducing subjectivity. CAR utilizes a standardized approach and has developed 20 protocols, contrasting with the VCS and Gold Standard which use over 200 project-specific methodologies and protocols (Broekhoff et al. 2019: 21).

The second problematic issue regarding additionality in project-by-project approaches is how to establish a baseline. A baseline predicts the quantity of emissions that would have happened in the absence of the offset credit, holding all other factors constant (Broekhoff et al. 2019: 23; Gillenwater 2012: 26). In other words, "a project's GHG reductions are quantified by comparing the actual emissions that occur after the project is implemented to its predicted baseline emissions" (Broekhoff et al. 2019: 23). Baselines are produced by negotiation between stakeholders (Michaelowa 2011: 18), which generates uncertainty among participants of carbon markets and can transform one additional project into non-additional with time or contextual changes.

Subjectivity project assessment creates multiple methodologies. Michaelowa (2011: 19), for example, notes that countries with environmental high standards might ask for datasets to define baselines, while host countries of participants working under less stringent environmental rulings will prefer simpler requirements. Although contextualizing projects might be a good practice for developing local capacities, it can be challenging for meeting quality standards, especially when the offset market grows (Gillenwater 2012: 14).

Another fundamental element to assess projects is time and the duration of crediting criteria. Time and permanence of projects matter, as they directly impact the volume of offset delivery (Michaelowa 2011: 19). Additionally, the timing of credit releases may influence project quality. Releasing credits for sale ahead of actual emission reductions or baselines may harm the project (Gehring and Phillips 2017: 4). As Table 10.2 suggests, different projects represent different risks and benefits. For example, reforestation generally works under long-term schemes (100 years or more) to effectively deliver the absorption volume from an offset program. Normally, offset programs have pre-defined timelines where policy intervention remains additional in time (Broekhoff et al. 2019; Gillenwater 2012). The peril of long-term projects is that they may lock in policy and technological innovation, making it difficult to verify and prevent leakage. This is why the EU banned forestry and land-use credits (World Bank 2019; PMR 2015). Facing new technologies, unexpected events (political or environmental), and new policies (global, national, or local) may require periodically reassessing the baseline to arrive at a flexible timeline or, as in Japan, none at all (World Bank 2019).

Offset providers rely upon certain strategies to prevent non-additionality. The first one is a robust methodological approach, most commonly dealing with (1) the documentation of alternative scenarios to the proposed project, (2) assessment of the financial obstacles projects encounter and how offset credits may help overcome them, and (3) a pre-determined catalog of projects (PMR 2015: 6). The second strategy is to implement crediting systems by sector, which may help prevent subjectivity 
and diverse methodologies when assessing offset project additionality, especially for jurisdictions not able to cap the entire economy, but aiming to evolve into more comprehensive trading systems. This strategy credits emissions reductions from a covered sector against a threshold, where credits are granted to projects initiated below a certain level (Egenhofer 2013: 366; Michaelowa 2011: 32). This is aided by establishing a threshold that can be expressed in absolute emissions, carbon intensity, or technological transfer (Fujiwara 2009: 44). The third strategy is for offset providers to guarantee their emission savings over time. If the project becomes non-additional, the provider promises to compensate by developing another project. Clark (2009: 47) showed that "as the offset market grows, some offset companies have enough capital to invest in projects speculatively: they fund an offset project and then sell the carbon savings once the cuts have actually been made".

\section{Overestimating Supply}

There are three ways in which the supply of projects can be problematic: (1) overestimating the GHG emissions reduction, (2) not having quality projects which grant socio-environmental co-benefits or even impact negatively in localities (Broekhoff et al. 2019: 23-24), and (3) not having enough projects for the offset programs. Overestimation occurs when the baseline is miscalculated and it establishes more potential reductions than they really are. Overestimation is also present when a project fails to account for leakage. Leakage occurs when taking care of one forest implies that agricultural activities just moved to some other area that will be deforested. A study by Haya (2019) suggests that $82 \%$ of the CARB offsets for forestry (36 projects) might present some sort of leakage and have been over-credited. Another source of leakage was $\mathrm{N}_{2} \mathrm{O}$, which relocated its production from the EU to developing countries, where CDM credits were more profitable (Michaelowa 2011: 29).

Preventing socio-environmental disadvantages is crucial for quality project development. For example, some need prior social consultation or even insistence upon co-benefits to localities (Broekhoff et al. 2019: 30). To help projects meet such qualifications and guarantee implementation requires participatory processes with indigenous peoples, local communities, international experts, and civil society. As Gehring and Phillips (2017: 4) note, "consultation is a key factor for nearly all top-level certification schemes". Further, quality offsets may even promote network cooperation among various participants. Martínez (2019: 252-253) asserts that collective work can address this purpose, where business, social entities, small-communitarian associations, or indigenous peoples cooperate in developing wind and solar energy projects, i.e., sharing property, management, and benefits. For example, the organization VERRA certifies that offset projects meet the Climate, Community, and Diversity Standard $(C C B)$ by assessing land management projects which benefit climate-change mitigation along with local community development and biodiversity. It also helps CARB projects follow the right sustainable protocols (VERRA 2020). 
Oversupply of projects is also dangerous. When an offset program allocates excess credits, prices tend to fall. This can be harmful when the system requires a fixed percentage of offsets: it may derail the program, especially in economic or global crises when emissions naturally tend to be reduced (Rabe 2018; Öko-Institut e.V. 2018). Flexibility may solve this issue by adjusting the emissions mitigation percentage the program covers. In other words, it might be necessary to temporarily or permanently withdraw a certain number of project offerings, as the EU ETS does, to keep the price as stable as possible (Michaelowa 2011: 30).

In contrast, under-supply deals with a poor quality offer of projects. Offset participants and jurisdictions tend to seek the most profitable, sometimes low-quality projects. As shown in Table 10.2 of the previous section, there are very few project types meeting quality criteria. Because of low quality, the EU ETS reduced its share of CDM as 2012-2020 offset options and banned credits in 2013 for certain mitigating activities, including capturing and destroying GHG emitted by landfills and feeding farm animals, or offsets from industrial pollutants (Meckling and Hepburn 2013: 482; Michaelowa 2011: 16). In a race to the bottom, companies participating in the EU offset program overproduced large amounts of HFC-23 and asked for credits to develop HFC-22, an only slightly less polluting gas (Schneider and La Hoz Theuer 2018).

Supply can also be adjusted when global crises emerge. For example, this is the case of the aviation industry during the COVID-19 pandemic. As Lang (2020: 1) notes, "it was expected that airlines bought offsets above a baseline set by the average of the aviation industry's emissions in 2019 and 2020. Because of the coronavirus pandemic, global air travel has fallen dramatically. As a result, the baseline is far lower than predicted, and airlines will have to buy far more offsets than anticipated". There is a debate over the need to include offsets from REDD+ into aviation (Carbon Pulse 2019; Egenhofer 2013; Yuvaraj 2011).

During the KP, there was an oversupply of projects; it was not difficult to find lowquality carbon offsets. The potential supply of GHG reductions was huge because there were so many GHG emission sources with no legal or economic incentives to change. With each country pledging to the Paris Agreement, however, quality project supply became complicated. The need to reach NDC goals or the existence of various offset programs worldwide may lead to the third problem, which is double counting.

\section{Double Counting}

When country or market participant "A" claims a certain emission reduction volume, it cannot count upon NDC mitigation registries or the cap of country or market participant "B". If it does, double-counting problems emerge: these are expressly prohibited by Article 4.13 of the Paris Agreement and clarified by its Article 6 (Broekhoff et al. 2019: 15-16; Obergassel and Asche 2017). Double counting, then, happens when two or more offset participants claim GHG reductions from the same project or when, through fraudulent practices or legitimate mistakes, accurate registration fails. This 
is the case in renewable energy projects, for example, when both consumer and producer, or the project and a power plant, claim the GHG reduction for the same clean electricity, and the offset program grants separate credits (Broekhoff et al. 2019: 25).

Defining the amount of GHG reduction per property clarifies credit ownership rights and may prevent double counting. There is a clear link between avoiding double-counting practices and project temporality (or permanence), where establishing a baseline and lifetime for the credit is fundamental. When credits are awarded, they should be retired from the market, or in the words of the Paris Agreement, the corresponding adjustments should be applied (Broekhoff et al. 2019: 16; Gehring and Phillips 2017: 4). If not, countries with NDCs would be tempted to reduce emissions through domestic policy while also selling a credit to a more polluting country (if technology came from there) for the same reduction. Robust counting methods and verification by third parties are needed to prevent "cheating" by splitting a credit in two. In other words, double counting implies reducing by half, which is said to have been mitigated (Carbon Market Watch 2019). Double counting can thus deter NDCs, as it did with the JI. JI had double-counting problems where both participants were committed under KP and claimed the same credit as their own (Elsworth et al. 2012; Elsworth and Worthington 2010). Among other reasons, this is why several voices are raised against using old KP mechanisms such as CDM, within the context of the Paris Agreement (Carbon Market Watch 2019; Environmental Defense Fund 2019; Dufrasne 2018).

Clark (2009) warns of another more subtle type of double counting. It occurs when different offset companies quote different prices for the same credit. This happens, he explains, because of overestimating GHC supply, as was discussed above. It may happen due to the project nature and type. If it is immersed in a Type $\mathrm{C}$ offset program, costs may be higher due to co-benefits. In this scenario, apart from external double counting (host country or sector with receiving partner), it can happen crosssector, within the same ETS. Double counting can also happen within offset programs themselves when policies or standards are credited simultaneously with projects (Michaelowa 2011: 16).

One iconic example of the perils of double counting is the aviation sector. The International Civil Aviation Organization (ICAO) is working together with the Paris Agreement institutions to develop its Carbon Offsetting and Reduction Scheme for International Aviation (CORSIA). Starting in 2021, this industry is committed to compensating for any increase in its GHG emissions under a 2020 baseline (Broekhoff et al. 2019: 16; Dufrasne). CORSIA has an "open architecture" design where airlines can purchase and retire offset credits issued by ICAO. Verification will be performed by various certification programs working for either ICAO or project developers. Given the different methodologies and participants, this could create a double-counting problem. Who records mitigation? The airline, company purchasing the ticket, or individual passenger? To avoid such fragmentation, unified double-counting rules must be created to meet environmental integrity (VERRA 
2017; Michaelowa 2011: 17-18). The fear of double counting for lack of coordinated methodologies was intensely discussed at COP25, especially when assessing the proposed inclusion of REDD+ projects into CORSIA.

To prevent double counting as established by Article 6 of the Paris Agreement, the Environmental Defense Fund (2019) proposed several exchanges among NDC countries with non-NDC and voluntary schemes for aviation (e.g. CORSIA) and the use of CDM. As COP25 in 2019 did not result in an agreement as to the functioning of carbon markets and how to deal with KP mechanisms, those protocols and rules are still pending. Robust double-counting prevention methods need to be put in place. Experts and international organizations (see Broekhoff et al. 2019; Environmental Defense Fund 2019; PMR 2015; Schneider et al. 2014) recommend preventing double counting with restrictive eligibility criteria, inventory-based accounting, emission balances (spare emissions vs. removals covered by conditional NDC), international accounting rules, tracking systems, and/or third-party verification.

Aside from recommendations under the Paris Agreement, there are other offset programs seemingly better suited to prevent double counting. For example, entities covered by the California and Quebec joint ETS can use $8 \%$ of their cap as offsets. This market prohibits issuing offset credits in sectors covered by ETS or those already under regulation in both jurisdictions (PMR 2015: 8).

To sum up, unclear additionality, problems with supply, and double counting are core issues that can derail any offset program and impact any ETS. New ETS and offset programs need to take into account these three issues before setting up operations. This applies to the nascent Mexican ETS, which includes an offset program. The next section explains how the pilot ETS has worked and how its offset program endeavours to face these three challenging issues.

\section{MexiCO2 ETS and Offset Program}

Mexico has participated in the UNFCCC since it was designed in 1992, ratifying all instruments and, though categorized as a Non-Annex country in the KP, setting pricing strategies for reducing emissions (e.g. taxes). The General Law on Climate Change (LGCC) enacted in 2012 offered a legal basis for developing policies, programs, and instruments to reach mitigation and adaptation goals. At COP21 in Paris, 2015, Mexico presented its NDC, which included two innovations. One disaggregated its goals into non-conditional (realistic goals the country could meet if policies were implemented) and conditional (needing external sources of funding to be put into place). The other innovation included black carbon in the covered commitments. The specific non-conditional commitments accounted for a reduction of GHG and short-term pollutants of $25 \%$ below business as usual by 2030 (22\% of GHG and $51 \%$ of black carbon). Conditional goals account for $36 \%$ GHG and $70 \%$ of black carbon reduction by 2050 (with a baseline at the year 2000). Peak emissions are estimated for 2026 (MexiCO2 2019b). 
In 2015, as part of a comprehensive energy and fiscal reform, Congress passed the Law for Energy Transition (LET) and other related laws. The LGCC and LET legally supported deploying carbon pricing instruments for reaching NDC goals; such as Clean Energy Certificates (CEC), carbon taxes, and ETS to start operating in 2023. Clean Energy Certificates (CEC) account for a certain amount of electricity generated from clean energy sources since 2014. This means that if a power plant generated clean energy before that year, they would not be able to obtain these certificates. Once clean energy is produced, its generators put CEC on the market; companies from consuming sectors needing to mitigate pollution could buy CEC to meet their obligations. CECs are auctioned by the National Center of Energy Control (CENACE) or may be traded on the spot market or through bilateral contracting.

Worth noting is that the federal government in power since 2018 made three decisions impacting the CEC market and the path to decarbonization. First, it cancelled any auctioning for electricity projects. In previous auctions, all awarded projects were for renewable energy deployment. Second, in October 2019, it changed the rules of CECs to include all Federal Electricity Commission (CFE) power plants (generating clean energy before and after 2014) to grant these certificates and put them on the market (DOF 2019b). Having been a monopoly for 70 years, CFE is thus guaranteed to receive the most CECs. Having CFE in the CEC market will result in oversupply, which will lower prices (García 2019). In 2016, CEC started at \$25USD per MW; by 2018 , the price dropped to \$18USD and future estimates are not optimistic. The third decision came in April 2020. It stated that, due to the 2020 COVID pandemic and for energy-security reasons, all renewable private providers would need to suspend activities; only CFE would stand (DOF 2020). Renewable-energy companies immediately filed for judicial protection against abuses of public authority (under the legal figure called "amparo"). Companies such as Mexsolar I, Dolores Wind, among others, won a provisional suspension in the courts against the government's ruling in May 2020 (Elceo 2020). One month later, Greenpeace Mexico and Centro Mexicano de Derecho Ambiental (CEMDA) won a definitive suspension (CEMDA 2020). As expected, these decisions had several consequences, among which were derailment of the CEC market and arrested renewable energy deployment in the country.

Apart from CECs, Mexico has three carbon taxes as pricing mechanisms. Two fall under the umbrella of Special Taxes Upon Services and Production (Impuesto Especial sobre Producción y Servicios [IEPS]). IEPS oil taxes fossil fuel imports; ISAN covers new car purchases. Most interesting is IEPS carbon, which sets GHG prices for different types of fuel. ${ }^{1}$ This is the only tax that can be paid through CDM offset credits. This model resembles that of South Africa, where 5 to $8 \%$ of carbon taxes can be covered by offset programs (Mehling and Dimanchev 2017: 24). Since 2018, the Mexican government has accepted CDM offsets to cover $20 \%$ of the tax payment, under certain conditions: they must be developed in Mexico and not emitted before 2014, they ought to be sold on the European Emissions Market, and they need to address post-Kyoto goals. Because of low prices ( $\varnothing 0.30 \mathrm{USD}$ per tonne), as of 2019, Mexican fiscal authorities had not received tax payments via offsets (MexiCO2 2019a). 
The first phase of the carbon market started in 2017 with a simulation program with no obligatory participant information disclosure, real data, or economic impact; it was a "role playing" exercise. The LGCC was reformed in 2018 to set a timeline for the second phase and future implementation of the ETS. The second phase directs participants into market trials divided into two periods. From January 2020 to December 2021, there is a pilot testing; from January 2022 to December, there will be a transitional testing program. The goal of this two-phase period is to prepare participants and familiarize them with market dynamics. Having a long-term testing period (36 months) may evidence the pressure of the Mexican industry resisting committing to real GHG reductions in a carbon market in the short-term, arguing loss of competitiveness (Arteaga 2019; Flores 2019). The Mexican ETS utilizes a most-polluting-sector approach; including facilities with in situ $\mathrm{CO}_{2}$ emissions of 100,000 tonnes for a given year after 2016. The participating sectors are as follows: fossil-fuel energy (deployment, production, distribution of oils; generation, transmission, distribution of electricity), large industries (automakers, cement, chemical, food and beverages, glass, mining, petrochemical, paper, iron, and steel), and other industries which emit from static sources. These sectors represent $45 \%$ of reported national emissions (DOF 2019a). The logic behind the decision is that energy companies and energy-intensive manufacturing regard ETS as imposing lower burdens than other pricing strategies (e.g. taxes) (Meckling and Hepburn 2013: 479).

The Mexican ETS includes two flexible mechanisms, offsets and early action. As Mehling and Dimanchev (2017: 30) note, having an offset program can help adjust the ETS cap and face short-term fluctuations and incoming policies. In the case of Mexico during ETS simulations, the offset program established that credits can cover up to $10 \%$ of emissions and cannot be linked to CECs (see results in Table 10.3). When the market officially starts operations in 2023, the inclusion of CECs will depend on their performance (e.g. in terms of prices).

Table 10.3 shows that the results of market simulations are very different, with the number of offsets having increased dramatically. This may be explained by price increases, which made offsetting a very competitive practice. When ETS implementation arrives in 2023, early action and offsets acquired during the trials may still be valid if no more than six months old. This is important because some early-action projects are already operating in Mexico through CDM or voluntary markets. As of 2016, there were 13 projects ranging from methane capture from landfills, to energy efficiency and wind and solar generation, to reforestation and sustainable forestry (see

Table 10.3 Offset results of the three-year market simulation

\begin{tabular}{l|l|l|l}
\hline & Simulation 1 (2017) & Simulation 2 (2018) & Simulation 3 (2019) \\
\hline $\begin{array}{l}\text { Offsets awarded to } \\
\text { government (tonnes) }\end{array}$ & $6,899,943$ & $13,676,755$ & $37,000,000$ \\
\hline $\begin{array}{l}\text { Prices of offsets } \\
\text { (Mexican pesos) }\end{array}$ & 54 & 83 & 198 \\
\hline
\end{tabular}

Source Author's elaboration with information from SEMARNAT (2018a, b), SEMARNAT (2017) 
Annex 1). These projects have been developed through CDM and voluntary markets such as GS, VCS, and Plan Vivo (MexiCO2 2016). As of 2020, for example, CAR reported one landfill and more than 25 forestry projects (Climate Action Reserve 2020).

To operate, Chapter IV of the Mexican ETS basis document (DOF 2019a) mandates the Ministry of Environment and Natural Resources (SEMARNAT) as its governing authority, for designing offset protocols and grant credits. Protocols will set proceedings, requirements, and methodologies to quantify emissions reduction, absorption, and prevention in eligible projects. During ETS simulations, participants could utilize previous projects as offsets as transaction instruments. As of 2018, the market simulation had a \$3-\$12USD price range.

In sum, Mexican stakeholders can utilize offset credits to pay for the IEPS carbon tax through CDM projects, enter into international voluntary offset programs, and use offset credits to improve reductions under ETS. As elsewhere, offset programs need to prevent non-additionality, overestimated supply, and double counting.

\section{Mexican Offset Program and Problematic Issues}

It seems unfair to judge the Mexican ETS offset program while it is still under construction: at the time of this article, offset protocols are still being drafted. Earlyaction projects and voluntary markets, and ETS simulations, even at this early stage, may suggest that the Mexican ETS offset program falls under Type A. It still has not addressed links with other climate policies and instruments such as CECs, GHG mitigation mechanisms, taxes, or other offset programs operating in Mexico. It certainly has no broad spillover effect into such other policy domains as poverty, education, or health. In this limited context, the Mexican offset program aims to address quality issues by mandating that projects be real, quantifiable, permanent, verifiable, and operative. Projects awarded during the ETS simulations have mainly been of medium quality, focusing on methane capture and use from landfills, followed by low-quality projects in forestry and large-scale renewable energy; with only three projects ranked as high quality due to co-benefits.

\section{Non-additionality}

To guarantee additionality, the Mexican ETS has been careful to prohibit offset projects which directly mitigate $\mathrm{CO}_{2}$. Offsets will need to fulfil almost the same criteria as that of CDM: developed on Mexican soil and verified by a third party. Still, of the projects registered under voluntary schemes, additionality may be questioned in the cases of projects for wind energy deployment from wind parks in Oaxaca and solar power in Baja California. As Table 10.2 suggests, additionality in 
the case of large-scale clean and renewable energy might not be considered additional. This can also apply to forestry projects, where community and local regulation in some rural (mostly indigenous) areas have often promoted local development through pluri-harvesting and improved agricultural management. These practices are traditional and may not strictly add up to emissions reduction, but they do directly address co-benefits (e.g. funding, greater income, market promotion, or biological diversification).

In contrast, version 2.0 of Mexico's forestry management offset protocol, approved by the California Action Reserve (2019), includes additionality tests. They guarantee that no forestry projects are developed without the offset program. Projects need to prove that they are not mandated by any law or regulation, and they must pass a performance test demonstrating that forests are in danger of changing their land use or losing their $\mathrm{CO}_{2}$ balance. While these tests analyse several formal elements (land property rights, local, state, and national regulation, environmental integrity, and cobenefits), they do not include implementation gaps. For example, projects may fail when there is the little governmental capacity to control rezoning practices, in either federal or public areas. A project may become non-additional in these situations, especially when the protocol allows for aggregating different economic activities into one project.

Another risk is that sustainable agroforestry in Mexico commonly faces security issues. Agroforestry areas in certain regions are also used by criminal organizations, which determines how territorial planning will be structured. Although this situation is off-limits for an ETS market, it threatens the viability of Mexican agroforestry projects. Additionality problems might also be present when accepting forests under short-term protection ${ }^{1}$ as eligible for credits: baseline and temporality may need to be adjusted over time. However, the protocol correctly assesses the difficulty of proving additionality for forest degradation, declaring these cases non-eligible.

\section{Oversupply}

In terms of supply, the offset program design still needs to address problems of leakage and to better promote high-quality projects offering broad co-benefits. Of the 13 projects reported by MexiCO2 (up through 2016), only three may be categorized as high-quality according to Table 10.2 (see Annex 1). Overestimation can also be problematic as Mexico's potential for offering offsets could rely on forestry and lowscale projects. Recalling the EU ETS experience, including REDD+ in the ETS offset can risk promoting low-quality projects. The main challenges to REDD+ projects in Mexico may be constantly renewed territorial planning. Leakage will be difficult to prevent in such long-term projects as forest conservation to take place over 100 years.

Another challenging issue deals with low demand and offers of offset credits and projects. Although it was just a market simulation, there has been low demand for

\footnotetext{
${ }^{1}$ Short-term protection implies that territories do not fall under the categories of national parks and natural protected areas. They are projects lasting about 3-5 years.
} 
offset credits by participants during this first phase of the program. In this context, the costs of certification for offset projects remain high (Santos 2019). Provision of clean and renewable projects can also affect offset demand and offer. As explained above, political decisions made by the current federal government are changing the structure of clean and renewable energy generation. As in the case of CECs, there will likely be an oversupply of CFE clean energy projects if, after 2023, the Mexican ETS accepts CECs as offset instruments.

\section{Double Counting}

To avoid double counting, the Mexican ETS base document establishes that offset projects must be listed in the National Emissions Registry (RENE) ${ }^{2}$ and to be immediately cancelled once credits are awarded. RENE registers projects directly linked to ETS as well as those issuing from CDM and voluntary programs. As explained earlier, offset projects are already functioning in Mexico. Of the projects mentioned above (see Annex 1), two of the projects reported by MexiCO2 (2016) also appear in CAR (2020) records (methane destruction in Yucatán and forest carbon capture in Santiago Tlacotepec, Estado de Mexico). This is inconsequential unless the two systems, Mexican and California ETS, want to count these projects as their own.

Another risk for double counting might be bilateral offset contracts. Such is the case of the Memorandum of Understanding signed between the California ETS and the Mexican State of Chiapas for forest offsetting (Government of California 2016). Although this initiative has not made any progress, the Mexican ETS should take care to prevent double counting of subnational bilateral offsetting that may not be reported to RENE.

\section{Conclusions and Recommendations}

Various ETS and offset schemes have proliferated over the last twenty years. CDM and JI were the first offset programs developed after the global climate governance structure began in 1992. To date, several failures are widely apparent, and the programs have sometimes been adverse to the very environmental goals they claimed to support. CDM and JI co-existed with other national and subnational offset programs, frequently unlinked to either of those flexible mechanisms. There are also voluntary markets promoting projects and standards.

Such fragmentation is detrimental for reaching a global common range of offset prices. Without global or regional pricing, climate policies (ETS, taxes, and offset programs) may suffer from a lack of common ground and an inability to review interconnected pricing systems (Michaelowa 2011: 17-18). A lack of interrelated

\footnotetext{
${ }^{2}$ Since 2016, the Mexican Emissions Registry (RENE) mandates all industries with more than $25,000 \mathrm{CO} 2$ eq tonnes to submit annual reports on emissions.
} 
pricing or failure to develop a centralized system undermine the notion that mitigation must be a global effort. In offset programs, fragmented pricing impacts project quality and standards, as diverse methodologies are put in place. The cases of CDM and JI prove that quality is necessary for legitimizing the use of market approaches to addressing climate change. Both flexible mechanisms had quality problems, which made some experts discredit them: as of now, it is unclear whether CDM and JI will continue to function under the Paris Agreement. A report by Dufrasne (2018) notes that lower expectations for NDCs (goals they can easily achieve), providing continuity in pollution offset, will result in "hot air" credits. In other words, they would just be a justification to emit and the end result would be an increase in global emissions; to date, there are about 20 gigatonnes of hot air in the NDCs.

The goal of this chapter was to present an overview of offset programs worldwide and discuss three principal issues they face: non-additionality, overestimated supply, and double counting. Although monitoring these issues generates substantial transaction costs (Michaleowa 2011), it is necessary to promote environmental integrity and guarantee that offsets are an attractive instrument for generating more mitigation than has been heretofore scheduled. If offset programs are developed with a broader scope (e.g. Types B and C), transaction costs may rise. However, if these types are combined with offset projects aiming for co-benefits and high quality, offset programs may offer solutions to support ETS or regulatory climate policies.

To address additionality problems in the Mexican ETS, it may be helpful to reduce subjectivity in eligibility criteria. Utilizing fewer methodologies or harmonizing them with verifiers (e.g. VCS or GS) is the first step. The second step might be to draft protocols that add flexibility to the eligibility criteria. For example, there needs to be a range of threshold percentages for when a project might prove additional over time (Gillenwater 2012). This flexibility needs to cover a diverse set of activities, some global, others occurring locally, with distinction also made between metropolitan and regional criteria.

Regarding supply issues, the promotion of co-benefits through prior social consultation seems appropriate for Mexico. To address low prices, decisions must be made regarding CFE's status as a potential main offset provider. As mentioned before, when the Mexican ETS starts operations in 2023, CECs might be linked to the offset program. Having a big clean-energy power producer as CFE may oversupply the nascent offset program (as it has done with the CEC market). Due to an excessive offer of credits by CFE, prices might be impacted with no interest from other market participants to account for these credits. It may also, with so little competition, prevent developing other sources of clean and renewable energy (e.g. distributed generation). Nonetheless, this may provide a window of opportunity for assuring quality (e.g. additionality and co-benefits), by undertaking alternative projects to benefit localities; it may be easier to prove that they could not be developed under the CFE offset credit monopoly. To promote this policy option within the current political context, it may be necessary to establish a two-threshold baseline, considering high (non-CFE) and low (CFE) project quality. This alternative route could also encourage local providers to continue developing projects with real, and broader, social co-benefits. Another 
option might be to offer support to early investors who promote new technology, allowing them to set their own offset percentages within the established range.

Preventing double counting will only be solved through transparency and a clear, current, and open RENE database. The Mexican offset program needs to acknowledge other forms of intentional and unintentional double counting, such as overlapping policies, regulations, or instruments. The easiest way to prevent external double counting is by linking the offset program to others worldwide.

Although the Mexican trading scheme is still in its first stage, it must address specific issues with its offset program. First, it needs to establish a clear relationship between other climate policy instruments such as international credits coming from CDM or national instruments like IEPS carbon or CECs. It may be that the Mexican ETS is transformed into a hybrid pricing strategy that includes ETS taxes and other regulatory policies (Michaelowa 2011). A clear link between all instruments prevents "regulatory cherry-picking" by market participants and helps stabilize prices.

Second, the Mexican offset program needs to establish project quality and standard protocols. MVR mechanisms, independent of ETS regulators, are fundamental to assessing offset projects (Meckling and Hepburn 2013). GS and VCS are key agents for evaluating projects within the Mexican offset program, which could, for example, work on a "double additionality" basis, where eligible projects must comply with specified co-benefits. In other words, co-benefits must be conceived as additional to the GHG mitigation additionality requirement. Third, ETS price stabilization is crucial. Experts suggest that in the future, setting price floors and ceilings is the best strategy (Michaelowa 2011: 30). This may also apply to the price range for offset programs, where prices must constantly rise to make the program attractive to market participants and project holders.

The use of offset programs worldwide has flourished. The variety of programs, however, impacts credit prices and indicates diverse methodologies and quality standards. Achieving quality is challenging, as projects often fall under non-additionality practices, GHG overestimation and leakage, and double counting. The Mexican ETS is on schedule to address these issues by combining strict eligibility criteria with highquality projects that include socio-environmental co-benefits, flexible use of credits to pay for other policy instruments, open data, and transparency.

\section{Annex 1}

See Tables 10.4 and 10.5. 
Table 10.4 Mexico's voluntary offset projects

\begin{tabular}{|c|c|c|c|c|c|}
\hline Project & Goal & Locality & $\begin{array}{l}\text { Voluntary } \\
\text { program }\end{array}$ & Co-benefits & Quality \\
\hline $\begin{array}{l}\text { Methane } \\
\text { capture and use } \\
\text { in } 27 \text { farms }\end{array}$ & $\begin{array}{l}\text { Generation of } \\
32,670 \mathrm{MW} / \mathrm{h} \\
\text { for self-use }\end{array}$ & Jalisco & $\mathrm{CDM}$ & $\begin{array}{l}\text { Job creation } \\
\text { Income increase } \\
\text { Odor management } \\
\text { Water conservation }\end{array}$ & Medium \\
\hline $\begin{array}{l}\text { Methane } \\
\text { capture and use } \\
\text { in landfill }\end{array}$ & $\begin{array}{l}\text { Reduction of } \\
100,000 \text { tonnes } \\
\text { of } \mathrm{CO}_{2} \text { per } \\
\text { year }\end{array}$ & Guanajuato & $\mathrm{CDM}$ & $\begin{array}{l}\text { Job creation } \\
\text { Health positive } \\
\text { effects } \\
\text { Odor management } \\
\text { Local government } \\
\text { savings on } \\
\text { electricity } \\
\text { (possibility to } \\
\text { re-invest these in } \\
\text { public services) }\end{array}$ & Medium \\
\hline $\begin{array}{l}\text { Methane } \\
\text { capture and use } \\
\text { in landfill }\end{array}$ & $\begin{array}{l}\text { Generation of } \\
1.95 \mathrm{MW}\end{array}$ & $\begin{array}{l}\text { Estado de } \\
\text { Mexico }\end{array}$ & $\mathrm{CDM}$ & $\begin{array}{l}\text { Job creation } \\
\text { Health positive } \\
\text { effects } \\
\text { Odor management } \\
\text { Local government } \\
\text { savings on } \\
\text { electricity } \\
\text { (possibility to } \\
\text { re-invest these in } \\
\text { public services) } \\
\end{array}$ & Medium \\
\hline $\begin{array}{l}\text { Methane } \\
\text { capture and use } \\
\text { in landfill }\end{array}$ & $\begin{array}{l}\text { Generation of } \\
2 \mathrm{MW} \\
\text { Reduction of } \\
833,396 \text { tonnes } \\
\text { of } \mathrm{CO}_{2} \text { in } \\
10 \text { years }\end{array}$ & Durango & CDM & $\begin{array}{l}\text { Job creation } \\
\text { Health positive } \\
\text { effects } \\
\text { Odor management } \\
\text { Local government } \\
\text { savings on } \\
\text { electricity } \\
\text { (possibility to } \\
\text { re-invest these in } \\
\text { public services) }\end{array}$ & Medium \\
\hline $\begin{array}{l}\text { Methane } \\
\text { capture and use } \\
\text { in landfill }\end{array}$ & $\begin{array}{l}\text { Generation of } \\
2 \text { to } 4 \mathrm{MW} \\
\text { Reduction of } \\
1,625,926 \\
\text { tonnes of } \mathrm{CO}_{2} \\
\text { in } 10 \text { years }\end{array}$ & Aguascalientes & $\mathrm{CDM}$ & $\begin{array}{l}\text { Job creation } \\
\text { Health positive } \\
\text { effects } \\
\text { Odor management } \\
\text { Local government } \\
\text { savings on } \\
\text { electricity } \\
\text { (possibility to } \\
\text { re-invest these in } \\
\text { public services) }\end{array}$ & Medium \\
\hline
\end{tabular}


Table 10.4 (continued)

\begin{tabular}{|c|c|c|c|c|c|}
\hline Project & Goal & Locality & $\begin{array}{l}\text { Voluntary } \\
\text { program }\end{array}$ & Co-benefits & Quality \\
\hline $\begin{array}{l}\text { Methane } \\
\text { capture and use } \\
\text { in landfill }\end{array}$ & $\begin{array}{l}\text { Generation of } \\
1.95 \mathrm{MW} \\
\text { Reduction of } \\
1,625,926 \\
\text { tonnes of } \mathrm{CO}_{2} \\
\text { in } 10 \text { years }\end{array}$ & Chihuahua & $\mathrm{CDM}$ & $\begin{array}{l}\text { Job creation } \\
\text { Health positive } \\
\text { effects } \\
\text { Odor management } \\
\text { Local government } \\
\text { savings on } \\
\text { electricity } \\
\text { (possibility to } \\
\text { re-invest these in } \\
\text { public services) }\end{array}$ & Medium \\
\hline $\begin{array}{l}\text { Reforestation } \\
\text { "Scolel'te" }\end{array}$ & $\begin{array}{l}\text { Capture } \mathrm{CO}_{2} \\
\text { in } 8,958 \mathrm{HA} \\
\text { Mixed } \\
\text { reforestation }\end{array}$ & Chiapas & Plan Vivo & $\begin{array}{l}\text { Increase } \\
\text { agricultural } \\
\text { production via } \\
\text { mixed } \\
\text { reforestation (trees } \\
\text { plus corn, beans, } \\
\text { fruits, coffee) } \\
\text { Reaching } 92 \\
\text { indigenous } \\
\text { communities } \\
\text { Help with } \\
\text { territorial planning }\end{array}$ & Medium \\
\hline $\begin{array}{l}\text { Sustainable } \\
\text { forestry }\end{array}$ & $\begin{array}{l}\text { Increase of } \\
1,270 \mathrm{HA} \text { of } \\
\text { forested area in } \\
40 \text { years } \\
\text { Reduction of } \\
7,758.129 \\
\text { tonnes of } \mathrm{CO}_{2} \\
\text { in } 40 \text { years }\end{array}$ & $\begin{array}{l}\text { Nayarit, } \\
\text { Tabasco, } \\
\text { Chiapas }\end{array}$ & VCS & $\begin{array}{l}\text { Poverty alleviation } \\
\text { Increase in the } \\
\text { commercialization } \\
\text { of "teca" wood } \\
\text { Job creation (fair } \\
\text { labour) } \\
\text { Support to rural } \\
\text { schools } \\
\text { Biodiversity } \\
\text { conservation }\end{array}$ & High \\
\hline $\begin{array}{l}\text { Renewable } \\
\text { energy } \\
\text { generation: } 3 \\
\text { wind parks }\end{array}$ & $\begin{array}{l}\text { Generation of } \\
360 \mathrm{MW} \\
\text { Prevent } \\
750,000 \text { tonnes } \\
\text { of } \mathrm{CO}_{2} \\
\end{array}$ & Oaxaca & $\begin{array}{l}\text { CDM } \\
\text { VCS }\end{array}$ & Job creation & Medium \\
\hline $\begin{array}{l}\text { Energy } \\
\text { efficiency: } \\
\text { Change of light } \\
\text { bulbs into } \\
\text { fluorescent } \\
\text { lamps }\end{array}$ & $\begin{array}{l}\text { Reaching } 57 \\
\text { million } \\
\text { families } \\
\text { Reduction of } \\
2.78 \text { million } \\
\text { tonnes of } \mathrm{CO}_{2} \\
\text { per year (in } \\
10 \text { years of the } \\
\text { project) }\end{array}$ & Countrywide & $\mathrm{CDM}$ & $\begin{array}{l}\text { Savings of } 14,900 \\
\text { million pesos in } \\
\text { electricity bills } \\
\text { Reduction on } \\
\text { federal subsidy to } \\
\text { electricity }\end{array}$ & Medium \\
\hline
\end{tabular}


Table 10.4 (continued)

\begin{tabular}{l|l|l|l|l|l}
\hline Project & Goal & Locality & $\begin{array}{l}\text { Voluntary } \\
\text { program }\end{array}$ & Co-benefits & Quality \\
\hline $\begin{array}{l}\text { Solar plant } \\
\text { "Aura Solar" }\end{array}$ & $\begin{array}{l}\text { Generate 82 } \\
\text { GW/h per year }\end{array}$ & Baja California & $\begin{array}{l}\text { CDM } \\
\text { VCS }\end{array}$ & Job creation & Medium \\
\hline $\begin{array}{l}\text { Efficient } \\
\text { kitchens "Utsil } \\
\text { Naj" }\end{array}$ & $\begin{array}{l}40,000 \\
\text { Kitchens } \\
100,000 \text { people }\end{array}$ & $\begin{array}{l}\text { Baja California, } \\
\text { Sonora, San } \\
\text { Luis Potosí, } \\
\text { Jalisco, } \\
\text { Guanajuato, } \\
\text { Estado de } \\
\text { México, } \\
\text { Michoacán, } \\
\text { Veracruz, } \\
\text { Oaxaca }\end{array}$ & $\begin{array}{l}\text { Goverty alleviation } \\
\text { Avoided } \\
\text { deforestation for } \\
\text { cooking of about } \\
40-60 \%\end{array}$ & High & \\
\hline $\begin{array}{l}\text { Forest } \\
\text { conservation in } \\
\text { Santiago } \\
\text { Tlacotepec }\end{array}$ & $\begin{array}{l}\text { CO capture of } \\
\text { approx. 25,000 } \\
\text { tonnes in } \\
6 \text { years }\end{array}$ & $\begin{array}{l}\text { Estado de } \\
\text { México }\end{array}$ & CAR & $\begin{array}{l}\text { Forest } \\
\text { conservation } \\
\text { Water conservation } \\
\text { Biodiversity } \\
\text { conservation }\end{array}$ & Low \\
\hline $\begin{array}{l}\text { Methane } \\
\text { destruction in } \\
\text { swine farm }\end{array}$ & $\begin{array}{l}\text { Destroy } \\
\text { Methane }\end{array}$ & Yucatán & CAR & $\begin{array}{l}\text { Residue used as } \\
\text { fertilizer } \\
\text { Odor management } \\
\text { Water conservation }\end{array}$ & High \\
\hline
\end{tabular}

Source MexiCO2 (2016) 
Table 10.5 CAR projects

\begin{tabular}{|c|c|c|c|c|}
\hline Project & Goal & Locality & Credits granted & Credits retired \\
\hline $\begin{array}{l}\text { Los Bancos } \\
\text { Forest }\end{array}$ & $\begin{array}{l}\text { Forest carbon } \\
\text { capture }\end{array}$ & Durango & 0 & 0 \\
\hline $\begin{array}{l}\text { San Lucas } \\
\text { Amanalco Forest }\end{array}$ & $\begin{array}{l}\text { Forest carbon } \\
\text { capture }\end{array}$ & Estado de Mexico & 0 & 0 \\
\hline $\begin{array}{l}\text { Santiago } \\
\text { Tlacotepec Forest }\end{array}$ & $\begin{array}{l}\text { Forest carbon } \\
\text { capture }\end{array}$ & Estado de Mexico & 0 & 0 \\
\hline $\begin{array}{l}\text { San Bartolo } \\
\text { Forest }\end{array}$ & $\begin{array}{l}\text { Forest carbon } \\
\text { capture }\end{array}$ & Estado de Mexico & 0 & 0 \\
\hline $\begin{array}{l}\text { San Nicolás } \\
\text { Tototlapan Forest }\end{array}$ & $\begin{array}{l}\text { Forest carbon } \\
\text { capture }\end{array}$ & Mexico City & 4,304 & 3,909 \\
\hline $\begin{array}{l}\text { San Jerónimo } \\
\text { Zacapexco Forest }\end{array}$ & $\begin{array}{l}\text { Forest carbon } \\
\text { capture }\end{array}$ & Estado de Mexico & 0 & 0 \\
\hline $\begin{array}{l}\text { San Rafael } \\
\text { Ixtapalucan } \\
\text { Forest }\end{array}$ & $\begin{array}{l}\text { Forest carbon } \\
\text { capture }\end{array}$ & Puebla & 0 & 0 \\
\hline $\begin{array}{l}\text { Santiago } \\
\text { Coltzingo Forest }\end{array}$ & $\begin{array}{l}\text { Forest carbon } \\
\text { capture }\end{array}$ & Puebla & 15,324 & 7,354 \\
\hline $\begin{array}{l}\text { Tecocomulco } \\
\text { ASRTulancingo }\end{array}$ & $\begin{array}{l}\text { Improved forest } \\
\text { management }\end{array}$ & Hidalgo & 0 & 0 \\
\hline $\begin{array}{l}\text { La Estancia } \\
\text { ASRTulancingo }\end{array}$ & $\begin{array}{l}\text { Improved forest } \\
\text { management }\end{array}$ & Hidalgo & 0 & 0 \\
\hline $\begin{array}{l}\text { Ixtula y Sembo } \\
\text { ASRTulancingo }\end{array}$ & $\begin{array}{l}\text { Improved forest } \\
\text { management }\end{array}$ & Hidalgo & 0 & 0 \\
\hline $\begin{array}{l}\text { Puentecillas y } \\
\text { Anexox } \\
\text { ASRTulancingo }\end{array}$ & $\begin{array}{l}\text { Improved forest } \\
\text { management }\end{array}$ & Hidalgo & 0 & 0 \\
\hline $\begin{array}{l}\text { San Pedro } \\
\text { Huixotitla } \\
\text { ASRTulancingo }\end{array}$ & $\begin{array}{l}\text { Improved forest } \\
\text { management }\end{array}$ & Hidalgo & 0 & 0 \\
\hline $\begin{array}{l}\text { El Ocote } \\
\text { ASRTulancingo }\end{array}$ & $\begin{array}{l}\text { Improved forest } \\
\text { management }\end{array}$ & Hidalgo & 0 & 0 \\
\hline $\begin{array}{l}\text { El Nopalillo } \\
\text { ASRTulancingo }\end{array}$ & $\begin{array}{l}\text { Improved forest } \\
\text { management }\end{array}$ & Hidalgo & 0 & 0 \\
\hline $\begin{array}{l}\text { Sangre de Cristo } \\
\text { ASRTulancingo }\end{array}$ & $\begin{array}{l}\text { Improved forest } \\
\text { management }\end{array}$ & Hidalgo & 0 & 0 \\
\hline $\begin{array}{l}\text { Los Romeros } \\
\text { ASRTulancingo }\end{array}$ & $\begin{array}{l}\text { Improved forest } \\
\text { management }\end{array}$ & Hidalgo & 0 & 0 \\
\hline $\begin{array}{l}\text { Sabanetas } \\
\text { ASRTulancingo }\end{array}$ & $\begin{array}{l}\text { Improved forest } \\
\text { management }\end{array}$ & Hidalgo & 0 & 0 \\
\hline $\begin{array}{l}\text { Emiliano Zapata } \\
\text { ASRTulancingo }\end{array}$ & $\begin{array}{l}\text { Improved forest } \\
\text { management }\end{array}$ & Hidalgo & 0 & 0 \\
\hline
\end{tabular}

(continued) 
Table 10.5 (continued)

\begin{tabular}{|c|c|c|c|c|}
\hline Project & Goal & Locality & Credits granted & Credits retired \\
\hline $\begin{array}{l}\text { El Ventorrillo } \\
\text { ASRTulancingo }\end{array}$ & $\begin{array}{l}\text { Improved forest } \\
\text { management }\end{array}$ & Hidalgo & 0 & 0 \\
\hline $\begin{array}{l}\text { San Lorenzo } \\
\text { Sayula } \\
\text { ASRTulancingo }\end{array}$ & $\begin{array}{l}\text { Improved forest } \\
\text { management }\end{array}$ & Hidalgo & 0 & 0 \\
\hline $\begin{array}{l}\text { Alhuajoyucan } \\
\text { ASRTulancingo }\end{array}$ & $\begin{array}{l}\text { Improved forest } \\
\text { management }\end{array}$ & Hidalgo & 0 & 0 \\
\hline $\begin{array}{l}\text { Hueyapan } \\
\text { ASRTulancingo }\end{array}$ & $\begin{array}{l}\text { Improved forest } \\
\text { management }\end{array}$ & Hidalgo & 0 & 0 \\
\hline $\begin{array}{l}\text { Cima de Togo } \\
\text { ASRTulancingo }\end{array}$ & $\begin{array}{l}\text { Improved forest } \\
\text { management }\end{array}$ & Hidalgo & 0 & 0 \\
\hline $\begin{array}{l}\text { Xahuayalulco } \\
\text { ASRTulancingo }\end{array}$ & $\begin{array}{l}\text { Improved forest } \\
\text { management }\end{array}$ & Hidalgo & 0 & 0 \\
\hline $\begin{array}{l}\text { Chacalapa } \\
\text { ASRTulancingo }\end{array}$ & $\begin{array}{l}\text { Improved forest } \\
\text { management }\end{array}$ & Hidalgo & 0 & 0 \\
\hline $\begin{array}{l}\text { Las Puentes y } \\
\text { Anexos } \\
\text { ASRTulancingo }\end{array}$ & $\begin{array}{l}\text { Improved forest } \\
\text { management }\end{array}$ & Hidalgo & 0 & 0 \\
\hline $\begin{array}{l}\text { Arturo Gomez } \\
\text { Canales } \\
\text { ASRTulancingo }\end{array}$ & $\begin{array}{l}\text { Improved forest } \\
\text { management }\end{array}$ & Hidalgo & 0 & 0 \\
\hline $\begin{array}{l}\text { Juan Lachao } \\
\text { Forest }\end{array}$ & $\begin{array}{l}\text { Forest carbon } \\
\text { capture }\end{array}$ & Oaxaca & 31,470 & 23,787 \\
\hline $\begin{array}{l}\text { Reforesting the } \\
\text { Usumacinta } \\
\text { River }\end{array}$ & $\begin{array}{l}\text { Improved forest } \\
\text { management }\end{array}$ & Campeche & 0 & 0 \\
\hline $\begin{array}{l}\text { Methane } \\
\text { recovery in swine } \\
\text { farm }\end{array}$ & $\begin{array}{l}\text { Methane } \\
\text { recovery }\end{array}$ & Yucatán & 575 & 0 \\
\hline $\begin{array}{l}\text { La Perseverancia } \\
\text { Biogas Plant }\end{array}$ & Energy & Morelos & 34,267 & 0 \\
\hline
\end{tabular}

Source Climate Action Reserve (2020) 


\section{References}

Alcock F (2008) Conflict and Coalitions within and across the ENGO Community. Global Environmental Politics 8(4):66-91

Alloisio I (2020) Article 6 of the Paris agreement: is no deal better than a bad deal? European University Institute (January 21). https://fsr.eui.eu/article-6-of-the-paris-agreement-is-no-dealbetter-than-a-bad-deal/

Arteaga JR (2019) Semarnat pone a prueba el ADN de las empresas. Forbes Mexico (December 16th). https://www.forbes.com.mx/semarnat-pone-a-prueba-el-adn-verde-de-las-empresas/

Broekhoff D, Gillenwater M, Colbert-Sangree T, Cage P (2019) Securing climate benefits: a guide to using carbon offset. Stockholm Environment Institute \& Greenhouse Gas Management Institute, Stockholm

Cames M, Harthan RO, Fussler J, Lazarus M, Lee CM, Erickson P, Spalding-Fecher R (2016) How additional is the clean development mechanism? Analysis of the application of current tools and proposed alternatives. Oko-Institut, INFRAS, Stockholm Environment Institute, Berlin

Carbon Market Watch (2019) COP25: No deal on UN carbon markets as a number of countries reject loopholes. Madrid (December 15th). https://carbonmarketwatch.org/2019/12/15/cop25-no-dealon-un-carbon-markets-as-a-number-of-countries-reject-loopholes/

CEMDA (2020) Conceden suspensión definitiva a amparo contra ley y política de generación de energía eléctrica. Mexico City: CEMDA. https://www.cemda.org.mx/conceden-suspension-def initiva-a-amparo-contra-ley-y-politica-de-generacion-de-energia-electrica/

Clark D (2009) The rough guide to green living. Penguin Books, London

Climate Action Reserve (CAR) (2019) Revisión del Protocolo Forestal para México. CAR, Mexico City. https://www.climateactionreserve.org/how/protocols/mexico-forest/revision-delprotocolo-forestal-para-mexico/

Climate Action Reserve (CAR) (2020) Projects. Climate Action Reserve, Los Angeles, CA. https:// www.climateactionreserve.org/how/projects/

DOF (Diario Oficial de la Federación) (2019a) Acuerdo por el que se establecen las bases preliminares del Programa de Prueba del Sistema de Comercio de Emisiones. DOF, Mexico City. http:// www.dof.gob.mx/nota_detalle.php?codigo $=5573934 \&$ fecha $=01 / 10 / 2019$

DOF (Diario Oficial de la Federación) (2019b) Acuerdo por el que se modifican los lineamientos que establecen los criterios para el otorgamiento de certificados de energías limpias y los requisitos para su adquisición, publicados el 31 de Octubre de 2014. DOF, Mexico City. https://www.dof. gob.mx/nota_detalle.php?codigo $=5576691 \&$ fecha $=28 / 10 / 2019$

DOF (Diario Oficial de la Federación) (2020) Acuerdo por el que se emite la política de confiabilidad, seguridad, continuidad y calidad del sistema eléctrico nacional. DOF, Mexico City. https://dof. gob.mx/nota_detalle.php?codigo $=5593425 \&$ fecha $=15 / 05 / 2020$

Dufrasne G (2018) The clean development mechanism: local impacts of a global system. Carbon Market Watch, Brussels

Egenhofer C (2013) The growing importance of carbon pricing in energy markets. In: Golthau A (ed) The handbook of global energy policy. Wiley-Blackwell, Chichester, UK

Elceo (2020) Seis empresas obtienen amparo contra freno de pruebas de energías limpias. Elceo, México City. https://elceo.com/negocios/tres-empresas-obtienen-amparo-contra-frenode-pruebas-de-energias-limpias/

Ellerman AD, Convery F, De Perthius C (2010) Pricing carbon: the European union emissions trading scheme. Cambridge University Press, Cambridge

Elsworth R, Worthington B (2010) E. R. Who? Joint implementation and the EU emissions trading system. Sandbag, London

Elsworth R, Worthington B, Morris D (2012) Help or hindrance? Offsetting in the EU ETS. Sandbag, London

Environmental Defense Fund (2019) Meeting the climate change goals of the Paris agreement. How to avoid double counting of emissions reductions. Environmental Defense Fund, New York 
Flores A (2019) El mercado mexicano de carbono, un componente crucial para enfrentar el cambio climático e impulsar la justicia social en México. World Resources Institute Mexico (January 28th). https://wrimexico.org/bloga/el-mercado-mexicano-de-carbono-un-componentecrucial-para-enfrentar-el-cambio-clim\%C3\%A1tico-e

Fujiwara N, Egenhofer C (2007) Shaping the global arena: preparing the EU emissions trading scheme for the post-2012 period. Centre for European Policy Studies, Brussels

Fujiwara N (2009) Flexible mechanisms in support of a new climate change regime: the CDM and beyond. CEPS Task Force Report, CEPS, Brussels, November

García JL (2019) ¿Qué son los CELs y por qué México podría dar la espalda a la lucha contra el cambio climático? (December 6th). Economía Hoy. https://www.economiahoy.mx/energia-mex ico/noticias/10241087/12/19/Que-son-los-CELs-y-por-que-Mexico-podria-dar-la-espalda-a-lalucha-contra-el-cambio-climatico.html

Gehring M, Phillips FK (2017) Intersections of the Paris agreement and carbon offsetting: legal and functional considerations (Paper No. 42). University of Cambridge, Cambridge

Gillenwater M (2012) What is additionality? Part 2: a framework for more precise definitions and standardized approaches, discussion Paper No. 002 (January). Silver Spring, MD: Greenhouse Gas Management Institute

Government of California (2016) California-Mexico Memorandum of Understanding on Climate Change \& the Environment. 2016 Progress Report. Government of California, California.

Hagelberg N (2019) Carbon offsets are not our get-to-jail free card. UN Environment, Nairobi. https://www.unenvironment.org/news-and-stories/story/carbon-offsets-are-not-our-getout-jail-free-card

Haya B (2019) ARB's U.S. Forest Projects offset protocol underestimates leakage-preliminary results. University of California, Berkeley

Lang C (2020) The aviation industry's denial of the climate crisis. REDD Monitor, April 10th. https://redd-monitor.org/2020/04/10/the-aviation-industrys-denial-of-the-climate-crisis/

López-Vallejo M (2014) Reconfiguring global climate governance in North America: a transregional approach. Routledge, London

Marcu A (2012) Expanding carbon markets through new market-based mechanisms. Centre for European Policy Studies, Brussels

Martínez N (2019) Imaginarios sociotécnicos y los futuros posibles de la transición energética en México. In: Tornel C (ed) Alternativas para limitar el calentamiento global en $1.5^{\circ}$ Más allá de la economía verde. Henrich Boll Stiftung, Mexico City, pp 238-267

Matsuki T (2015) Project-Based Carbon Offset Program, Carbon Pricing Training Workshop. World Bank, Vietnam

Meckling J, Hepburn C (2013) Economic instruments for climate change. In: Falkner R (ed) The handbook of global climate and environmental policy. Chichester UK, Wiley-Blackwell, pp 465485

Secretaría de Medio Ambiente y Recursos Naturales (SEMARNAT) (2017) Ejercicio de Simulación del mercado de Carbono en México. Reporte de Resultados de la Segunda Simulación. SEMARNAT-MexiCO2, Mexico City

Secretaría de Medio Ambiente y Recursos Naturales (SEMARNAT) (2018a) Ejercicio de Simulación del mercado de Carbono en México. Reporte de Resultados de la Tercera Simulación. SEMARNAT-MexiCO2, Mexico City

Secretaría de Medio Ambiente y Recursos Naturales (SEMARNAT) (2018b) Ejercicio de Simulación del mercado de Carbono en México. Reporte de Resultados de la Segunda Fase. SEMARNAT-MexiCO2, Mexico City

Mehling M, Dimanchev E (2017) Achieving the Mexican mitigation targets: options for an effective carbon pricing policy mix. SEMARNAT-GIZ, Mexico City

MexiCO2 (2016) Proyectos-Mercado Voluntario de Carbono. MexiCO2, Mexico City. http:// www.mexico2.com.mx/proyectos-de-carbono.php

MexiCO2 (2019a) Nota Técnica. Impuesto al Carbono en México. MexiCO2, Mexico City 
MexiCO2 (2019b) Nota Técnica. Sistema de Comercio de Emisiones en México. MexiCO2, Mexico City

Michaelowa A (2011) Fragmentation of international climate policy-doom or boon for carbon markets? In: UNEP Riso Centre (ed) Progressing towards post-2012 carbon markets. UNEP Riso Centre, Denmark, pp 13-23

Millard-Ball A, Ortolano L (2010) Constructing carbon offsets: the obstacles to quantifying emission reductions. Energy Policy 38(1):533-546

Monbiot G (2006) Selling indulgences. The guardian (19 October), London. https://www.monbiot. com/2006/10/19/selling-indulgences/

Obergassel W, Asche F (2017) Shaping the Paris mechanisms part III: an update on submissions on Article 6 of the Paris agreement. Wuppertal Institute for Climate, Environment and Energy, Wuppertal, GR

Öko-Insitut e.V. (2018) Designing an emissions trading system in Mexico: options for setting an emissions cap. Öko-Institute e.V., GIZ, SEMARNAT, Freiburg

PMR (Partnership for Market Readiness) (2015) Overview of carbon offset programs. Similarities and differences. World Bank, Washington DC

Carbon Pulse (2019) Shades of REDD+: Should forests offsets be eligible for CORSIA? Carbon Pulse (December 3rd). https://carbon-pulse.com/87946/

Rabe BG (2018) Can we price carbon? MIT, Cambridge

Santos P (2019) Experiencias de México con el mix de políticas de precio al carbono. MexiCO2, Mexico City

Schneider L, Kollmuss A, Lazarus M (2014) Addressing the risk of double-counting emission reductions under the UNFCCC. SEI working paper No. 2014-02. Stockholm Environment Institute, Seattle, WA

Schneider L, La Hoz Theuer S (2018) Environmental integrity of international carbon market mechanisms under the Paris agreement. Clim Policy 19(3):386-400. https://doi.org/10.1080/146 93062.2018.1521332

Schneider L (2007) Is the CDM fulfilling its environmental and sustainable development objectives? An evaluation of the CDM and options for improvement. Oeko-Institut and WWF, Berlin

Swyngedouw E (2016) CO2 as neoliberal fetish: the love of crisis and the depoliticized immunobiopolitics of climate change governance. In: Cahill D, Cooper M, Konings M, Primrose D (eds) The SAGE handbook of neoliberalism. Sage Handbooks, London, UK, pp 238-276

UNFCCC (United Nations Framework Convention on Climate Change) (1997) Kyoto protocol. UNFCCC

UNFCCC (United Nations Framework Convention on Climate Change) (2015) Paris agreement

Verra (2017) Double counting in ICAO's CORSIA: issues and solutions. https://verra.org/doublecounting-in-icaos-corsia-issues-and-solutions/

Verra (2020) Climate, community and biodiversity standards. https://verra.org/project/ccb-program/ Wara MW, Victor DG (2008) A realistic policy on international carbon offsets, Working Paper \#74. Stanford University, Stanford

World Bank (2019) State and trends in carbon pricing. World Bank, Washington DC

Yuvaraj NDB (2011) Voluntary market—future perspective. In: UNEP Riso Centre (ed) Progressing towards post-2012 carbon markets. UNEP Riso Centre, Denmark, pp101-110

Zhang X, Zhou L (2020) Subnational climate-change policies in China. In: Harvard project on climate agreements, overview and framing: climate-change policy in China. Subnational climatechange policy in China. Harvard Project on Climate Agreements, Harvard, pp 25-27 
Open Access This chapter is licensed under the terms of the Creative Commons Attribution 4.0 International License (http://creativecommons.org/licenses/by/4.0/), which permits use, sharing, adaptation, distribution and reproduction in any medium or format, as long as you give appropriate credit to the original author(s) and the source, provide a link to the Creative Commons license and indicate if changes were made.

The images or other third party material in this chapter are included in the chapter's Creative Commons license, unless indicated otherwise in a credit line to the material. If material is not included in the chapter's Creative Commons license and your intended use is not permitted by statutory regulation or exceeds the permitted use, you will need to obtain permission directly from the copyright holder.

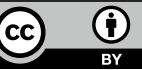

